\title{
Lipoma Arborescens
}

\author{
Preethy Murthy ${ }^{1}$, Puvitha R.Duraisami ${ }^{2 *}$ and Murthy M. ${ }^{1}$ \\ 'Department of Pathology,Karpagam Faculty of Medical Sciences and Research, Coimbatore, Tamil Nadu. (India).. \\ ${ }^{2}$ Department of Pathology, Coimbatore Medical College Coimbatore, Tamil Nadu (India).
}

\section{Dear Sir}

Lipoma arborescens is a rare intra articular lesion consisting of sub synovial villous proliferation of mature fat cells, presents with monoarticular or polyarticular ${ }^{\left[{ }^{[1]}\right.}$ It is an uncommon cause of intra-articular masses, as slowly progressive, painless swelling of the joint, with intermittent joint pain, in most of the cases it can be very well predicted by MRI. ${ }^{[2]}$ This report describes a case a 46-year-old woman who presented with an intermittent left knee joint pain and effusion for more than year duration. The complete rheumatological work up and the routine blood investigations were done; all were within normal limits. However, radiological examination of bilateral knees, suggests features of osteoarthritis .The ultrasonographic (USG) examination of bilateral knees was done which revealed hyperechoic, frond like projections of the synovium with effusion suggestive of lipoma arborescence. The patient was advised arthroscopic synovectomy of knee joint. Grossly, the received specimen show frond like villous /papillary projections of fibro fatty tissue. Microscopically, the hyperplastic synovium show many papillary projections which are lined by hyperplastic synovium, with sub synovial tissue replaced with mature adipocytes concludes the diagnosis of lipoma arborescens.(Fig.1).

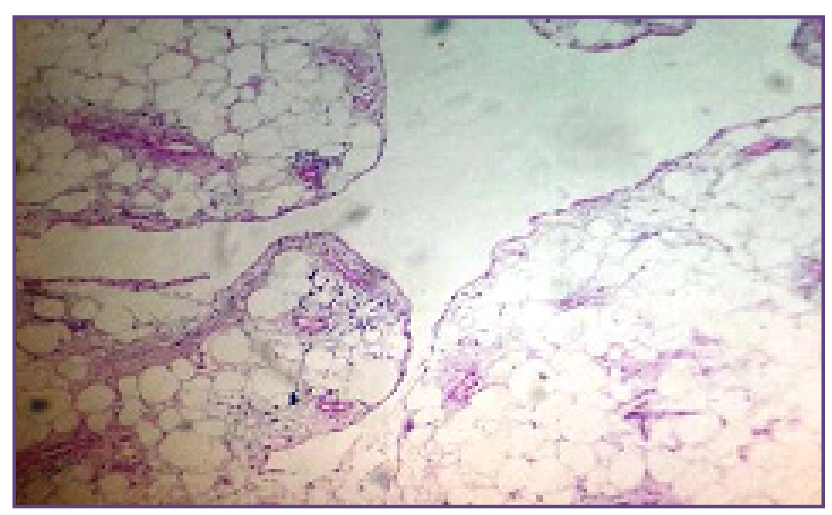

Fig. 1: show papillary projections, with sub synovial tissue replaced with mature adipocytes.
Albert Hoffa, a German surgeon, made the first description of lipoma arborescens in the year 1904; the Latin term arbor means 'tree-like appearance', describing the characteristic villous and frond-like morphology of this condition. Lipoma arborescence has been observed in patients aged between 9 and 68 years, equally in men and women. There are two etiological hypotheses, primary and secondary; primary idiopathic, rare commonly seen in younger group, whereas the more common secondary type associates with an underlying chronic irritation, usually seen in elderly patients. ${ }^{[2]}$

The differential diagnosis includes, synovial lipoma, pigmented villonodular synovitis, synovial chondromatosis, rheumatoid arthritis, synovial haemangioma, and xanthomata.

The main differential is synovial lipoma, macroscopically it appear as fatty polyp with adipocytes, where in Lipoma arborescences show hyperplastic synovium with subsynovial adipocytes. PVNS show many giant cells with haemosiderin pigments, Synovial chondromatosis show atypical chondrocytes in the synovium Rheumatoid arthritis show lymphoplasmacytic infiltrate with variable germinal centers, in contrast to Lipoma arborescences. ${ }^{[3]}$ Lipoma arborescences is a rare intra articular tumor with benign indolent course, awareness of its clinical and imaging findings and possible differential diagnosis is essential for early diagnosis and treatment, as well as to avoid misinterpretation with other aggressive articular masses.

\section{Reference}

1. Al-Sharim MM. Intra-articular lipoma arborescens of the knee joint. Ann Saudi Med 2011; 31(2):194-196.

2. Sanamandra SK, Ong KO. Lipoma Arborescens. Singapure Med J. 2014 Jan; 55(1):5-11.

3. Kamaran MSF, Kavin K, Sharma V, Shivanand G. Bilateral lipoma arborescens with osteoarthritis knee: Case report and literature review of Literature. J Clin Orthop Trauma.2015 Jan; 6(2):131-136.

*Corresponding author:

Puvitha R. Duraisami, Kappiniya Gounder Layout M.K.P.Colony,Ganapathy,Coimbatore. - 641 032. Tamil Nadu. India.

Phone: +91 9843112163 .

Email: drrdpuvitha@yahoo.com

Date of Submission : 13.11.2016

Date of Acceptance : 03.04.2017

Financial or other Competing Interests: None.
Date of Publication : 31.08.2017 